\title{
PENGARUH KONSENTRASI BAHAN PEMUCAT DAN JENIS BAHAN PENGENDAP TERHADAP PEMBENTUKAN SODIUM ALGINAT DARI RUMPUT LAUT COKLAT Sargassum filipendula C. AGARTH
}

\author{
Jamal Basmal"), Yuyun Sekarasih"), dan Tatit K. Bunasor**)
}

\begin{abstract}
ABSTRAK
Penelitian perbaikan kualitas sodium alginat telah dilakukan dengan menggunakan tiga konsentrasi hidrogen peroksida $\left(\mathrm{H}_{2} \mathrm{O}_{2}\right)$ sebagai bahan permucat yaitu $3 \%, 6 \%$, dan $9 \%(\mathrm{v} / \mathrm{V})$ yang kemudian diendapkan menggunakan dua jenis bahan pengendap yaitu sodium karbonat $\left(\mathrm{Na}_{2} \mathrm{CO}_{3}\right)$ $5 \%(\mathrm{~b} / \mathrm{v})$ dan sodium hidroksida $(\mathrm{NaOH}) 5 \%(\mathrm{~b} / \mathrm{v})$. Jenis rumput laut yang digunakan pada penelitian ini adalah rumput laut coklat Sargassum filipendula C. Agarth. Hasil penelittian menunjukkan bahwa konsentrasi $\mathrm{H}_{2} \mathrm{O}_{2}$ berpengaruh nyata terhadap derajat putih, kandungan logam $\mathrm{Pb}$, dan $\mathrm{Hg}$ tetapi tidak berpengaruh nyata terhadap rendemen, kekentalan, kadar susut pengeringan, kadar abu, dan kandungan logam As. Sedangkan jenis bahan pengendap berpengaruh nyata terhadap rendemen, derajat putih, logam berat $(\mathrm{Hg})$ tetapi tidak berpengaruh nyata terhadap parameter mutu lainnya. Kombinasi perlakuan terbaik ditemukan pada penggunaan $\mathrm{H}_{2} \mathrm{O}_{2} 6 \%$ dengan jenis bahan pengendap $\mathrm{NaOH} 5 \%$ yang menghasilkan rendemen sebesar $13,5 \%$; kekentalan 237,8 cps; kadar susut pengeringan (CAW) 14,5\%; derajat putih $53.7 \%$; kadar abu $25,3 \%$; kandungan logam berat $A s=1,083 \mathrm{ppb}$; logam dan kandungan logam $\mathrm{Hg}$ sebesar 1,5 $\mathrm{ppb}$
\end{abstract}

ABSTRACT: Effect of bleaching agent concentration and type of chemical precipitant agents to form sodium alginate from brown seaweed (Sargassum filipendula C. Agarth). By: Jamal Basmal, Yuyun Sekarasih, and Tatit K. Bunasor

Experiment to improve the quality of sodium alginate was carried out using three concentrations of hydrogen peroxide $\left(\mathrm{H}_{2} \mathrm{O}_{2}\right)$ i.e. $3 \%, 6 \%$, and $9 \%(\mathrm{v} / \mathrm{V})$. Alginate acid was purified by using two types of chemical precipitant $\left(\mathrm{Na}_{2} \mathrm{CO}_{3}\right.$ and $\left.\mathrm{NaOH}\right)$ with concentration of $5 \%(\mathrm{~W} / \mathrm{V})$ respectively. Brown seaweed Sargassum filipendula C. Agarth was used in this experiment. Results of experiment showed that $\mathrm{H}_{2} \mathrm{O}_{2}$ concentration significantly affected the degree of whiteness, $\mathrm{Pb}$ and $\mathrm{Hg}$ content, but not the yield, viscosity, clean anhydrous seaweed, ash, and Arsenic (As) content. Meanwhile types of precipitant gave significant effect to the yield, degree of whiteness, mercury $(\mathrm{Hg})$ content, but not to the other quality parameters. The best treatment found was the combination of $\mathrm{H}_{2} \mathrm{O}_{2} 6 \%$ as bleaching agent and $\mathrm{NaOH} 5 \%$ as precipitant giving $13.5 \%$ yield; $237 \mathrm{cps}$ viscosity; $14.5 \%$ clean anhydrous seaweed; $53.7 \%$ degree of whiteness; $25.3 \%$ ash content; 1.083 arsenic content; and $1.5 \mathrm{ppb} \mathrm{Hg}$ content

KEYWORDS: hydrogen peroxide, sodium carbonate, sodium hydroxide, brown seaweed, sodium alginate

\section{PENDAHULUAN}

Penelitian teknik ekstraksi sodium alginat dari rumput laut coklat telah banyak dilakukan (Chapman \& Chapman, 1980; Chou \& Chiang, 1976; King, 1983; Sari, 1994; Yani, 1988; Wiwekaningtyas, 1994). Pada umumnya jenis bahan kimia yang digunakan adalah sodium karbonat, asam klorida, potasium klorida, dan bahan pemutih sodium hipoklorid. Proses ekstraksi rumput laut coklat dilakukan dalam suasana basa yang bertujuan untuk memisahkan selulosa dari alginat. Bahan pengekstrak yang dapat digunakan adalah $\mathrm{Na}_{2} \mathrm{CO}_{3}$ atau $\mathrm{NaOH}$. Chou \& Chiang (1976) menyatakan bahwa konsentrasi $\mathrm{Na}_{2} \mathrm{CO}_{3}$ yang tingg (3\%-5\%) dapat menyebabkan penurunan rendemen dan kekentalan produk. Selanjutnya dikatakan bahwa penggunaan basa kuat dapat mendegradasi asam alginat dengan memotong rantai polimer menjadi oligosakarida dan terdegradasi lanjut menjadi asam4-deoksi-5-ketouronat. Faktor lain yang mempengaruhi kualitas alginat yang dihasilkan adalah proses pemanasan, yakni pemanasan dengan suhu

Peneliti pada Pusat Riset Pengolahan Produk dan Sosia! Ekonomi Kelautan dan Perikanan

Mahasiswa Institut Pertanian Bogor

Pengajar di Institut Pertanian Bogor 
tinggi akan mudah terjadi proses pencoklatan alginat yang diperoleh, tetapi dengan adanya proses pemanasan tersebut membuat proses ekstraksi lebih mudah dan dapat mengekstrak alginat dengan bobot molekul tinggi, sehingga dapat meningkatkan rendemen dan derajat kekentalan alginat.

Winarno (1990) menyatakan alginat yang memiliki mutu food grade maupun pharmaceutical grade harus bebas dari kandungan selulosa dan zat warna (warna alginat mendekati warna kuning gading, ivory color), Sedangkan untuk industrial grade warna yang masih terkandung di dalam sodium alginat tidak merupakan masalah faktor utama dalam menentukan kualitas sodium alginat yang dihasilkan. Menurut Murtini et al. (2000 ${ }^{\mathrm{ab}}$ ) dan Basmal et al. (2000), tanpa pemberian perlakuan pemucatan terhadap ekstraksi sodium alginat tidak akan diperoleh sodium alginat yang sesuai dengan standar Food Chemical Codex (FCC) (Anonim, 1981). Selanjutnya dinyatakan bahwa sodium alginat mutu pangan harus berwarna kuning gading sampai dengan warna putih. Oleh sebab itu pada penelitian ini tidak dilakukan pengamatan sodium alginat tanpa pemberian bahan pemucat. Pada proses pemucatan bertujuan untuk melarutkan zat warna yang terkandung di dalam larutan alginat kasar yaitu senyawa fenolik yang terdapat di dalam ikatan polimer alginat sehingga dapat diperoleh larutan yang lebih jernih. Jenis bahan pemucat yang biasa digunakan dalam proses pemucatan rumput laut coklat adalah sodium hipoklorida ( $\mathrm{NaOCl}$ ) atau hidrogen peroksida $\left(\mathrm{H}_{2} \mathrm{O}_{2}\right)$. Proses pemucatan menggunakan $\mathrm{NaOCl}$ tidak menimbulkan busa dan berlangsung relatif cepat (Yani, 1988), namun demikian Tseng (1946) menyarankan penggunaan $\mathrm{NaOCl}$ tidak lebih dari satu persen, karena penggunaan yang berlebihan akan menyebabkan alginat dapat teroksidasi dan terdegradasi.

Bahan pemucat hidrogen peroksida lazim digunakan di dalam mendegradasi warna menjadi warna putih baik untuk produk pangan maupun non-pangan. Diketahui bahwa $\mathrm{H}_{2} \mathrm{O}_{2}$ memiliki kecenderungan yang kuat untuk membebaskan oksigen, maka bahan ini bisa digunakan untuk reaksi oksidasi pada suhu rendah. Prinsip kerja dari $\mathrm{H}_{2} \mathrm{O}_{2}$ adalah akan menguraikan $\mathrm{H}_{2} \mathrm{O}_{2}$ menjadi $\mathrm{H}_{2} \mathrm{O}$ dan $\mathrm{O}_{n}$. Pembentukan sodium alginat adalah melalui reaksi pertukaran ion $\mathrm{H}^{+}$dari asam alginat menggunakan larutan alkali yang mengandung ion $\mathrm{Na}+$ seperti $\mathrm{NaOH}$ atau $\mathrm{Na}_{2} \mathrm{CO}_{3}$. Tujuan pembentukan sodium alginat adalah untuk mendapatkan alginat dalam bentuk yang lebih stabil. Menurut McHugh (1987), pertukaran ion $\mathrm{H}^{+}$dengan ion $\mathrm{Na}^{+}$berjalan lambat yaitu dengan mengatur nilai $\mathrm{pH}$ media berkisar antara $\mathrm{pH}$ 9-11,2. Kelebihan penggunaan larutan pengendap akan menyebabkan kadar abu menjadi tinggi dan kemungkinan akan diperoleh sodium alginat yang mempunyai nilai kekentalan rendah. Untuk mencapai penetralan homogen tidak mudah karena tergantung bagaimana larutan alkali dapat melakukan penetrasi ke dalam partikel asam alginat dengan baik. Larutan pengendap $\mathrm{NaOH}$ mempunyai kemampuan yang berbeda dengan $\mathrm{Na}_{2} \mathrm{CO}_{3}$ dalam bereaksi dengan asam alginat. Karena $\mathrm{NaOH}$ termasuk basa kuat, penggunaannya sebagai bahan pengendap alginat dari rumput laut coklat relatif lebih sedikit dibandingkan $\mathrm{Na}_{2} \mathrm{CO}_{3}$

Tujuan dilakukan penelitian ini adalah untuk memperoleh teknologi pengolahan sodium alginat yang sesuai dengan standar komersial dan untuk mengoptimalkan pemanfaatan rumput laut coklat sebagai bahan baku industri.

\section{BAHAN DAN METODE}

\section{Bahan}

Rumput laut yang digunakan pada penelitian ini adalah rumput laut coklat dari jenis Sargassum filipendula C. Agarth yang diperoleh dari Pantai Binuangeun pada bulan Juni 1998. Setelah rumput laut dipanen, langsung dijemur di bawah sinar matahari selama dua hari kemudian rumput laut tersebut dikemas di dalam kantong plastik untuk dibawa ke Pusat Riset Pengolahan Produk dan Sosial Ekonomi Kelautan dan Perikanan. Bahan kimia yang digunakan untuk mengekstrak alginat adalah bahan kimia teknis, seperti $\mathrm{Na}_{2} \mathrm{CO}_{3}, \mathrm{H}_{2} \mathrm{O}_{2}, \mathrm{HCl}$, dan $\mathrm{KOH}$ teknis

\section{Metode}

Metode yang digunakan untuk meningkatkan kualitas alginat adalah pertama-tama rumput laut coklat kering direndam dalam larutan $\mathrm{KOH} 0,75 \%$ selama 60 menit, dikeringkan, kemudian dilakukan pemotongan. Ekstraksi alginat dilakukan dengan memodifikasi metode Yunizal et al. (1997) yakni diekstrak menggunakan natrium karbonat, penyaringan, dan disarikan menggunakan $\mathrm{HCl}$. Asam alginat yang diperoleh kemudian diendapkan selama 5-10 menit menggunakan dua jenis bahan kimia yaitu $\mathrm{Na}_{2} \mathrm{CO}_{3} 5 \%$ (b/v) (P1) dan $\mathrm{NaOH} 5 \%$ (b/v) (P2), sedangkan untuk pemucat digunakan hidrogen peroksida dengan konsentrasi $\mathrm{H}_{2} \mathrm{O}_{2}\left(\mathrm{H}_{1}=3 \%, \mathrm{H}_{2}=\right.$ $6 \%$, dan $\mathrm{H} 3=9 \%(\mathrm{v} / \mathrm{v})$. Sodium alginat yang terbentuk dipisahkan menggunakan alkohoi teknis, dikeringkan, kemudian ditepungkan menjadi sodium alginat. Rancangan yang digunakan untuk menentukan hasil terbaik adalah rancangan acak lengkap faktorial dua faktor yang terdiri atas tiga konsentrasi $\mathrm{H}_{2} \mathrm{O}_{2}(\mathrm{H} 4=$ $3 \%, \mathrm{H} 2=6 \%$, dan $\mathrm{H} 3=9 \%(\mathrm{~V} / \mathrm{V})$ dan dua taraf bahan pengendap yaitu $\mathrm{Na}_{2} \mathrm{CO}_{3} 5 \%$ (P1) dan $\mathrm{NaOH} 5 \%$ (b/v) (P2). Percobaan diulang sebanyak dua kali. Pada penelitian ini perlakuan perendaman dengan air untuk pemucatan tidak dilakukan karena Basmal (1999), 
Murtini et al. (2000 a,b), dan Basmal (2000) telah menemukan bahwa tanpa menggunakan bahan pemucat tidak akan menghasilkan sodium alginat yang berwarna putih seperti yang dipersyaratkan untuk sodium alginat food grade.

Tepung sodium alginat yang diperoleh dianalisis mutunya baik secara kimiawi maupun secara fisik seperti uji rendemen, nilai kekentalan, susut pengeringan, derajat putih, kadar abu, arsen (As), dan merkuri $(\mathrm{Hg})$

\section{HASIL DAN BAHASAN}

\section{Rendemen}

Nilai rata-rata rendemen sodium alginat yang dihasilkan berkisar antara 9,3\%-13,5\%. Rendemen tertinggi dihasilkan oleh kombinasi perlakuan pemucatan dengan $\mathrm{H}_{2} \mathrm{O}_{2} 6 \%(\mathrm{H} 2)$ dan diendapkan dengan $\mathrm{Na}_{2} \mathrm{CO}_{3} 5 \%$ (P1), sedangkan nilai rendemen terkecil ditemukan pada kombinasi perlakuan antara $\mathrm{H} 2$ dengan bahan pengendap $\mathrm{NaOH} 5 \%$ (P2). Pada Gambar 1 dapat dilihat fluktuasi rendemen setelah mendapatkan kombinasi perlakuan. Hasil uji sidik ragam pada selang kepercayaan $95 \%$ menunjukkan bahwa konsentrasi bahan pemutih $\mathrm{H}_{2} \mathrm{O}_{2}$ dan jenis bahan pengendap tidak berpengaruh nyata terhadap rendemen, tetapi interaksi kedua perlakuan tersebut memberikan hasil yang berpengaruh nyata terhadap nilai rendemen. Hasil uji lanjut wilayah berganda Duncan menunjukkan bahwa perlakuan H2P1 tidak berbeda nyata dengan H1P2 tetapi berbeda nyata dengan perlakuan lainnya (H3P1, H3P2, H1P1, dan H2P2), sedangkan keempat perlakuan lainnya tidak saling berbeda dalam hal rendemen sodium alginat yang dihasilkan. Pada Gambar 1 dapat terlihat bahwa penggunaan bahan pemucat hingga 3\% dapat meningkatkan kadar rendemen bila diendapkan dengan $\mathrm{Na}_{2} \mathrm{CO}_{3}$, tetapi sebaliknya nilai tertinggi rendemen tercapai bila pengendap menggunakan $\mathrm{NaOH}$ dengan konsentrasi bahan pemucat $6 \%$.

Proses pemucatan telah menyebabkan pigmen yang terkandung di dalam rumput laut coklat teroksidasi dan terdegradasi. Peningkatan konsentrasi $\mathrm{H}_{2} \mathrm{O}_{2}$ dari $3 \%$ hingga $6 \%$ kemudian diendapkan menggunakan $\mathrm{NaOH}(5 \%)$ menyebabkan rendemen mengalami peningkatan. Hal ini diduga disebabkan sebagian pigmen fukosantin telah dapat dibebaskan sehingga memudahkan pembentukan asam alginat yang kemudian pada waktu pengendapan dengan $\mathrm{NaOH}$ jumlah sodium alginat yang terbentuk semakin tinggi. Namun demikian peningkatan konsentrasi $\mathrm{H}_{2} \mathrm{O}_{2}$ dari $6 \%$ menjadi $9 \%$ telah mengakibatkan jumlah rendemen yang dihasilkan menjadi berkurang. Diduga pada konsentrasi $\mathrm{H}_{2} \mathrm{O}_{2} 9 \%$ telah terjadi pemutusan rantai gugus alginat menjadi gugus yang lebih sederhana sehingga pada saat diendapkan dengan $\mathrm{NaOH}$ jumlah alginat yang dapat bereaksi dengan ion $\mathrm{Na}^{+}$lebih sedikit. Menurut Percival (1970), pemakaian konsentrasi bahan pemucat yang terlalu tinggi dapat mendegradasi alginat sehingga pada waktu diendapkan dengan asam klorida $(\mathrm{HCl})$ atau asam sulfat $\left(\mathrm{H}_{2} \mathrm{SO}_{4}\right)$ alginat yang telah mengalami degradasi tersebut tidak akan terendapkan.

\section{Nilai Kekentalan}

Nilai rata-rata kekentalan sodium alginat yang dihasilkan berkisar antara $120 \mathrm{cp}-266,8 \mathrm{cp}$ pada konsentrasi larutan sodium alginat sebesar $1 \%$ yang

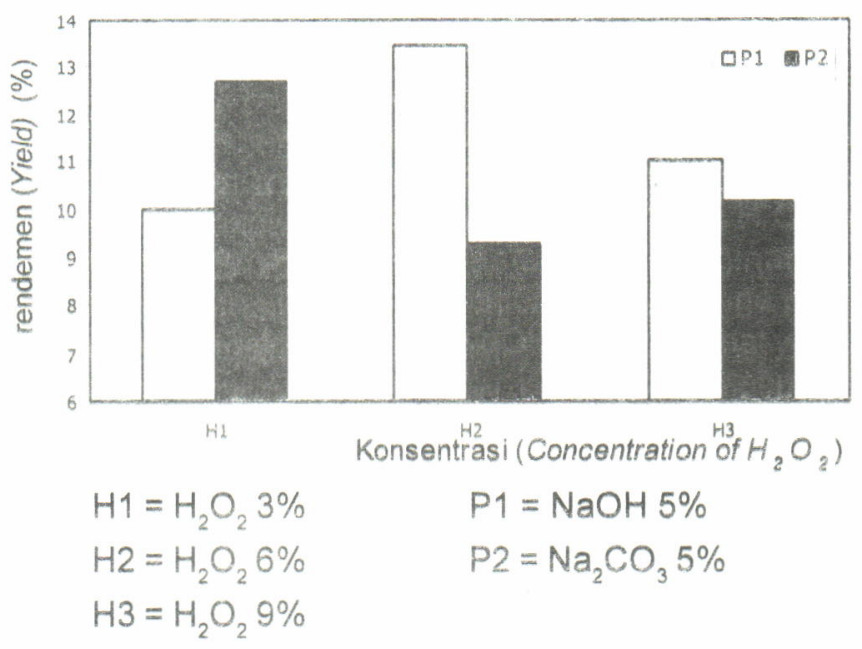

Gambar 1. Rendemen sodium alginat dari berbagai kombinasi perlakuan pemucatan dan pengendapan

Figure 1. The yield of sodium alginate treated by different concentration of bleaching agent and precipitant 
diukur pada suhu $25^{\circ} \mathrm{C}$. Nilai kekentalan tertinggi diperoleh dari kombinasi perlakuan $\mathrm{H}_{2} \mathrm{O}_{2} 9 \%$ dan diendapkan dengan $\mathrm{NaOH} 5 \%$. Sedangkan nilai kekentalan terendah ditemukan pada perlakuan konsentrasi $\mathrm{H}_{2} \mathrm{O}_{2} 3 \%$ dan diendapkan dengan $\mathrm{Na}_{2} \mathrm{CO}_{3}$ $5 \%$.

Hasil uji statistik menunjukkan bahwa pemakaian bahan pemucat $\mathrm{H}_{2} \mathrm{O}_{2}$ pada konsentrasi 3\% hingga 9\% tidak berpengaruh nyata pada taraf $5 \%$ terhadap nilai kekentalan sodium alginat, akan tetapi pemakaian bahan pengendap berpengaruh. Winarno (1990) menyatakan bahwa nilai kekentalan sodium alginat bervariasi dari $10 \mathrm{cp}$ sampai $5.000 \mathrm{cp}$ dan semakin tinggi nilai kekentalan maka kualitas sodium alginat semakin baik. Pada penelitian ini nilai kekentalan tetinggi mencapai $266,8 \mathrm{cp}$ sehingga dikelompokkan ke dalam kualitas sedang. Penggunaan $\mathrm{H}_{2} \mathrm{O}_{2}$ sebagai bahan pemucat sodium alginat telah menyebabkan terjadinya degradasi alginat, semakin banyak alginat yang terdegradasi maka semakin banyak pula rantai polimer alginat yang terputus sehingga akan menghasilkan sodium alginat dengan bobot molekul yang lebih rendah. Sodium alginat dengan bobot molekul rendah akan memberikan nilai kekentalan yang rendah pula. Menurut McHugh (1987), semakin tinggi bobot molekul dan konsentrasi alginat maka viskositas larutan sodium alginat akan semakin tinggi, sebaliknya semakin rendah bobot molekul maka nilai kekentalan larutan alginat semakin rendah pula.

Hasil uji wilayah berganda Duncan's dapat diketahui bahwa penggunaan bahan pengendap $\mathrm{NaOH}$ memberikan hasil yang berbeda nyata dibandingkan dengan penggunaan bahan pengendap $\mathrm{Na}_{2} \mathrm{CO}_{3}$. Pada
Gambar 2 dapat dilihat bahwa penggunaan $\mathrm{NaOH}$ sebagai bahan pengendap mempunyai nilai kekentalan lebih tinggi dibandingkan dengan penggunaan $\mathrm{Na}_{2} \mathrm{CO}_{3}$ sebagai bahan pengendap sodium alginat. Penurunan nilai kekentalan diduga karena terbentuknya residu garam sebagai akibat reaksi asam alginat dengan $\mathrm{NaOH}$ maupun $\mathrm{Na}_{2} \mathrm{CO}_{3}$. Chapman \& Chapman (1980) menyatakan bahwa nilai kekentalan sangat dipengaruhi oleh penambahan dalam jumlah sedikit garam seperti $\mathrm{NaCl}, \mathrm{Na}_{2} \mathrm{SO}_{4}, \mathrm{Na}_{2} \mathrm{CO}_{3}$, dan garam sodium amonium. Pada penelitian ini asam alginat yang telah terbentuk dicuci dengan air suling namun masih mempunyai kelebihan asam $(\mathrm{HCl})$. Kelebihan $\mathrm{HCl}$ tersebut pada saat pengendapan menggunakan $\mathrm{NaOH}$ maupun $\mathrm{Na}_{2} \mathrm{CO}_{3}$ akan membentuk garam $\mathrm{NaCl}$. Menurut McHugh (1987), untuk mencapai penetralan homogen tidak mudah karena tergantung dari alkali (bahan pengendap) melakukan penetrasi terhadap partikel asam alginat. Diduga kemampuan ion $\mathrm{Na}^{+}$ yang berasal dari $\mathrm{Na}_{2} \mathrm{CO}_{3}$ lebih reaktif dibandingkan ion $\mathrm{Na}^{+}$yang berasal dari $\mathrm{NaOH}$ untuk membentuk residu garam $(\mathrm{NaCl})$. Cottrel \& Kovacs (1980) menyatakan bahwa keberadaan garam monovalen $0,5 \%$ seperti $\mathrm{NaCl}$ dapat menekan kekentalan larutan sodium alginat.

\section{Derajat Putih}

Nilai rata-rata derajat putih sodium alginat berkisar antara $53,7 \%-87,3 \%$. Nilai derajat putih tertinggi ditemukan pada perlakuan kombinasi konsentrasi $\mathrm{H}_{2} \mathrm{O}_{2} 9 \%$ yang diendapkan dengan $\mathrm{Na}_{2} \mathrm{CO}_{3} 5 \%$, sedangkan nilai terendah ditemukan pada perlakuan

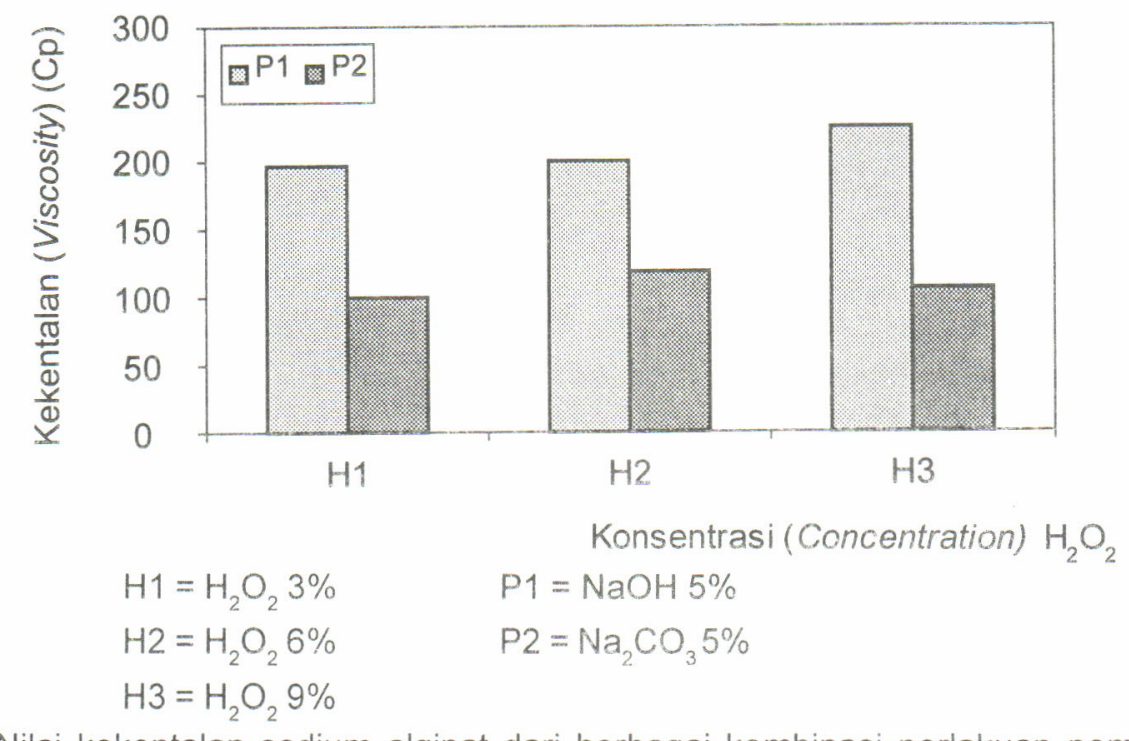

Gambar 2. Nilai kekentalan sodium alginat dari berbagai kombinasi perlakuan pemucatan dan pengendapan

Figure 2. Viscosity of sodium alginate treated by different concentration of bleaching agent and precipitant 


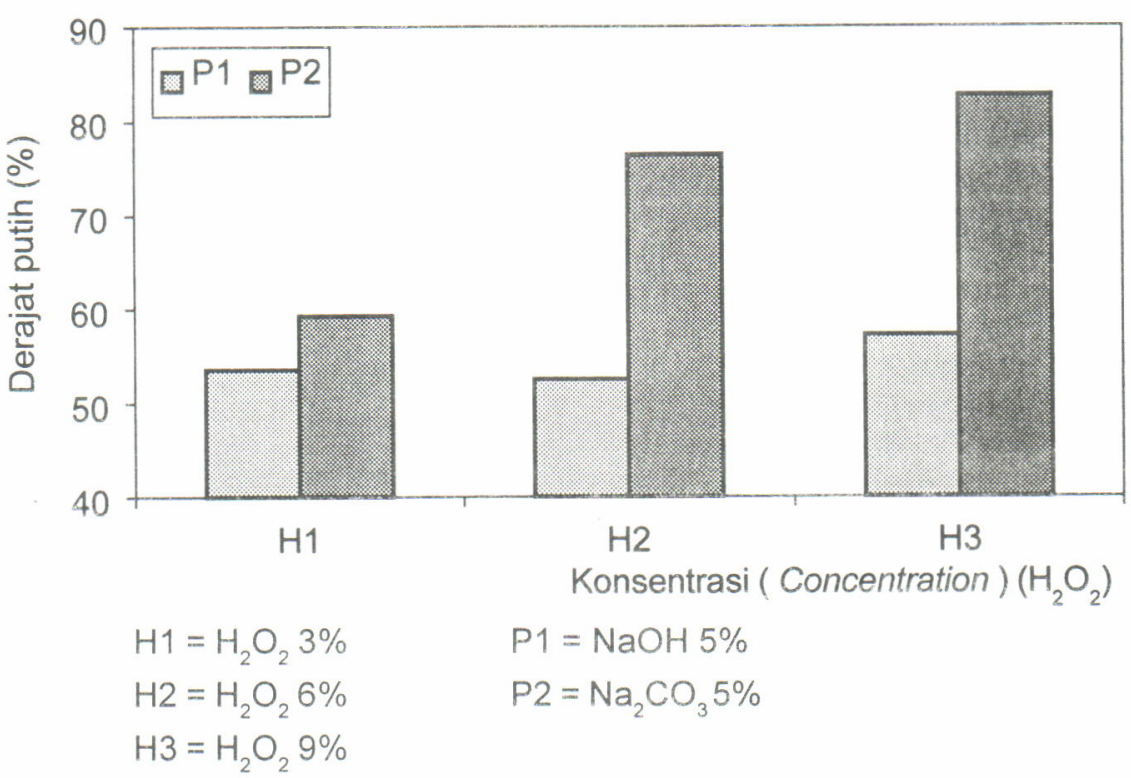

Gambar 3. Nilai derajat putih sodium alginat dari berbagai kombinasi perlakuan pemucatan dan pengendapan

Figure 3. Whiteness value of sodium alginate treated by different concentration of bleaching agent and precipitant

kombinasi antara konsentrasi $\mathrm{H}_{2} \mathrm{O}_{2} 6 \%$ yang diendapkan dengan $\mathrm{NaOH}$ \% (Gambar 3).

Hasil uji sidik ragam menunjukkan bahwa faktor $\mathrm{H}$, dan faktor $\mathrm{P}$ masing-masing berpengaruh nyata pada level $5 \%$ terhadap derajat putih sodium alginat yang dihasilkan. Namun demikian interaksi antara faktor $\mathrm{H}$ dan faktor $\mathrm{P}$ tidak menunjukkan pengaruh yang nyata pada level 5\%. Hasil uji lanjut wilayah berganda Duncan's menunjukkan bahwa konsentrasi $\mathrm{H}_{2} \mathrm{O}_{2} 9 \%$ tidak berbeda nyata dengan $\mathrm{H}_{2} \mathrm{O}_{2} 6 \%$, tetapi berbeda nyata dengan $\mathrm{H}_{2} \mathrm{O}_{2} 3 \%$. Sedangkan $\mathrm{H}_{2} \mathrm{O}_{2}$ pada konsentrasi $6 \%$ tidak berbeda nyata dengan konsentrasi $\mathrm{H}_{2} \mathrm{O}_{2} 3 \%$. Jenis bahan pengendap $(\mathrm{NaOH}$ atau $\mathrm{Na}_{2} \mathrm{CO}_{3}$ ) ternyata memberikan pengaruh yang nyata terhadap peningkatan derajat putih.

Pada Gambar 3 dapat dilihat bahwa semakin tinggi konsentrasi $\mathrm{H}_{2} \mathrm{O}_{2}$ yang dipergunakan telah menyebabkan nilai derajat putih semakin tinggi. Fukosantin, salah satu pigmen yang terkandung di dalam rumput laut coklat, tidak larut dalam air dan tidak dapat dihilangkan dengan cara merendam di dalam air, tetapi bila ditambahkan zat pemucat seperti penambahan $\mathrm{H}_{2} \mathrm{O}_{2}$, fukosantin tersebut menjadi sangat labil dan mudah teroksidasi (Anonim, 1981). Semakin tinggi konsentrasi bahan pemucat yang diberikan maka proses pemucatan akan berjalan semakin sempurna akan tetapi telah menyebabkan nilai kekentalan semakin menurun. Pada penelitian ini nilai derajat putih tertinggi ditemukan pada penggunaan konsentrasi yang lebih tinggi yaitu konsentrasi $\mathrm{H}_{2} \mathrm{O}_{2} 9 \%$. Diketahui bahwa $\mathrm{H}_{2} \mathrm{O}_{2}$ memiliki kecenderungan yang kuat untuk membebaskan oksigen sehingga dapat digunakan di dalam reaksi oksidasi pada suhu rendah. Sifat $\mathrm{H}_{2} \mathrm{O}_{2}$ sebagai oksidator kuat mampu mengoksidasi gugus kromofor di dalam rumput laut coklat. Semakin tinggi $\mathrm{H}_{2} \mathrm{O}_{2}$ yang ditambahkan maka semakin banyak pula gugus kromofor yang teroksidasi

\section{Kadar Abu}

Nilai rata-rata kadar abu sodium alginat yang dihasilkan berkisar antara 20,1\%-27,5\% (Gambar 4).

Hasil uji sidik ragam menunjukkan bahwa konsentrasi bahan pemucat $(H)$, bahan penendap $(P)$, dan interaksinya tidak berpengaruh nyata pada taraf $5 \%$. Untuk mendapatkan nilai terbaik diantara semua perlakuan dapat dibandingkan dengan standar yang telah ditentukan oleh FCC. Standar FCC menetapkan bahwa kadar abu sodium alginat berkisar antara $18 \%$ sampai $27 \%$. Hasil penelitian kombinasi perlakuan yang sesuai kadar abunya dengan standar FCC adalah H1P2 sebesar 20,1\%; H2P1 $=25,3 \% ; H 2 P 2=24,2 \%$; dan H3P2 sebesar $26,9 \%$

\section{Logam Berat Arsen (As)}

Nilai rata-rata kandungan logam As di dalam sodium aiginat hasil ekstraksi berkisar antara 0,140 ppb $-1,665$ ppb (Gambar 5).

Hasil analisis ragam bahan pengendap $(P)$ dan interaksi kombinasi antara bahan pemucat $(\mathrm{H})$ tidak menunjukkan perbedaan yang nyata pada taraf $5 \%$, tetapi menunjukkan perbedaan yang nyata pada 


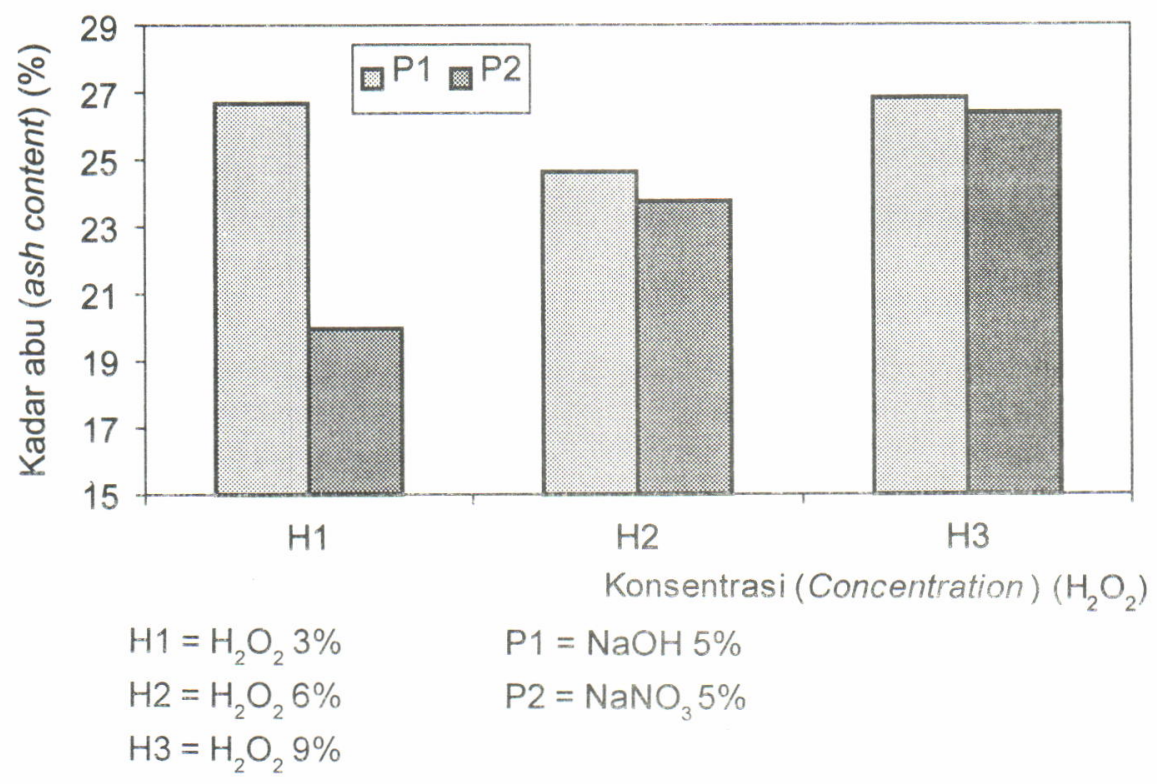

Gambar 4. Kadar abu sodium alginat dari berbagai kombinasi perlakuan pemucatan dan pengendapan Figure 4. Ash content of sodium alginate treated by different concentration of bleaching agent and precipitant

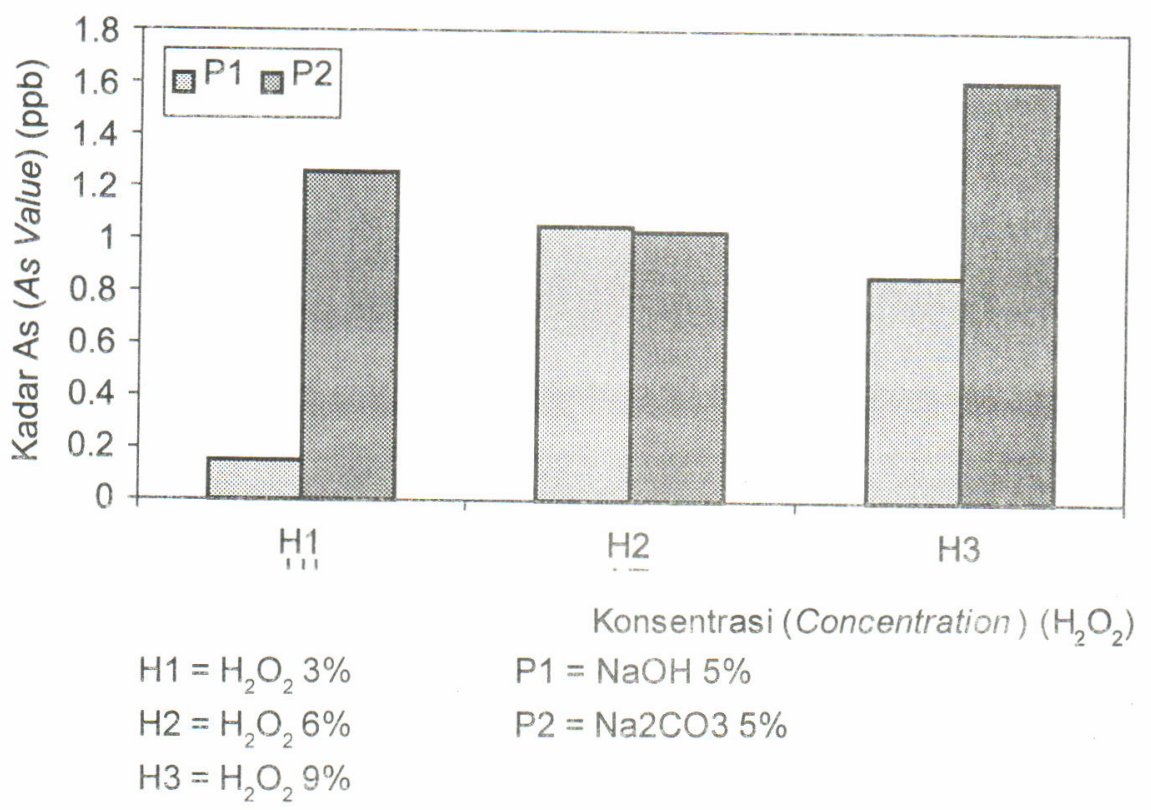

Gambar 5. Kadar arsen (As) sodium alginat dari berbagai kombinasi perlakuan pemucatan dan pengendapan

Figure 5. Arsenic (As) content of sodium alginate treated by different concentration of bleaching agent and precipitant

penggunaan konsentrasi $\mathrm{H}_{2} \mathrm{O}_{2}$ yang berbeda. Hasil uji perbandingan wilayah Duncan's untuk konsentrasi bahan pemucat $(\mathrm{H})$ terhadap logam berat menunjukkan bahwa nilai logam berat As tertinggi ditemukan pada perlakuan ( $\mathrm{H} 3)$ yakni konsentrasi $\mathrm{H}_{2} \mathrm{O}_{2} 9 \%$, sedangkan antara perlakuan $\mathrm{H}_{2}$ dan $\mathrm{H} 1$ yakni konsentrasi masing-masing $3 \%$ dan $6 \%$ tidak berbeda nyata.
Untuk mengetahui kombinasi perlakuan terbaik dapat dibandingkan dengan standar FCC, yakni kandungan logam As harus lebih kecil dari $3 \mathrm{mg} / \mathrm{L}$, sedangkan nilai kandungan logam keenam kombinasi perlakuan adalah paling besar $1,67 \times 10^{-3} \mathrm{ppb}$ yang berarti semua perlakuan kombinasi masih jauh di bawah standar yang di tetapkan oleh FCC. Kandungan logam berat di dalam thallus rumput laut sangat dipengaruhi oleh kondisi perairan tempat rumput laut 
tersebut tumbuh. Hasil penelitian menunjukkan bahwa kandungan logam berat masih di bawah standar FCC yang berarti wilayah perairan Lempasing, Propinsi Lampung tempat diambilnya rumput laut S. filipendula C Agarth diduga kandungan logam As masih rendah. Ini terlihat dari akumulasi logam As di dalam rumput laut coklat yang masih jauh di bawah standar yang ditetapkan oleh FCC.

\section{Logam Hg}

Nilai rata-rata kandungan logam berat $\mathrm{Hg}$ pada sodium alginat berkisar antara 1,5 ppb hingga 11,5 $\mathrm{ppb}$. Kandungan logam $\mathrm{Hg}$ terendah ditemukan pada perlakuan kombinasi H2P1, H2P2, dan H3P1. Ketiga perlakuan kombinasi tersebut mempunyai nilai yang tidak berbeda nyata antara satu dengan yang lainnya yaitu sebesar 1,5 ppb; sedangkan nilai logam berat $\mathrm{Hg}$ tertinggi ditemukan pada perlakuan kombinasi $\mathrm{H} 1 \mathrm{P} 1$, yaitu pemucatan dengan $\mathrm{H}_{2} \mathrm{O}_{2} 3 \%$ dan diendapkan dengan $\mathrm{NaOH}$ 5\% (Gambar 6).

Hasil uji statistik menunjukkan bahwa antara konsentrasi bahan pemucat $(\mathrm{H})$ dan bahan pengendap (P) dan interaksi keduanya berpengaruh nyata terhadap kandungan logam berat $\mathrm{Hg}$, sedangkan dari hasil uji lanjut wilayah berganda Duncan's menunjukkan bahwa antara konsentrasi bahan pemucat $(H)$ berbeda nyata satu dengan yang lainnya, dengan nilai kandungan logam berat terendah ditemukan pada konsentrasi bahan pemucat $\mathrm{H}_{2} \mathrm{O}_{2} 6 \%$, sedangkan tertinggi ditemukan pada konsentrasi bahan pemucat $\mathrm{H}_{2} \mathrm{O}_{2} 9 \%$. Hasil uji wilayah berganda Duncan's terhadap pengaruh penggunaan bahan pengendap alginat ternyata pemakaian antara $\mathrm{NaOH}$ dan $\mathrm{Na}_{2} \mathrm{CO}_{3}$ memberikan pengaruh yang saling berbeda dengan nilai kandungan logam berat terendah ditemukan pada perlakuan penggunaan bahan pengendap $\mathrm{NaOH} 5 \%$. Sedangkan interaksi antara faktor $\mathrm{H}$ dengan faktor $\mathrm{P}$ juga memberikan pengaruh yang saling berbeda antara perlakuan kombinasi yang diberikan kecuali perlakuan kombinasi $\mathrm{H}_{2} \mathrm{P}_{2}, \mathrm{H}_{2} \mathrm{P}_{1}$, dan $\mathrm{H}_{3} \mathrm{P}_{1}$ tidak saling berpengaruh, begitu pula antara perlakuan kombinasi antara $\mathrm{H}_{3} \mathrm{P}_{2}$ dengan $\mathrm{H}_{1} \mathrm{P}_{1}$ tidak saling berpengaruh. Standar kandungan logam berat yang telah ditetapkan oleh FCC yaitu kurang dari 0,004\%. Dibandingkan dengan standar maka kandungan logam $\mathrm{Hg}$ dalam sodium alginat yang dihasilkan jauh lebih. Oleh sebab itu semua perlakuan kombinasi yang diberikan telah memenuhi syarat FCC. Adanya logam berat $\mathrm{Hg}$ pada sodium alginat yang dihasilkan diduga berasal dari wilayah perairan tempat tumbuh rumput laut $S$. filipendula dan merupakan ion organik.

\section{KESIMPULAN}

Konsentrasi $\mathrm{H}_{2} \mathrm{O}_{2}$ tidak berpengaruh terhadap rendemen, kekentalan, kadar susut pengeringan, dan kadar abu, namun demikian berpengaruh terhadap derajat putih. Sedangkan perlakuan penggunaan bahan pengendap terhadap sodium alginat memberikan pengaruh nyata terhadap kekentalan dan derajat putih.

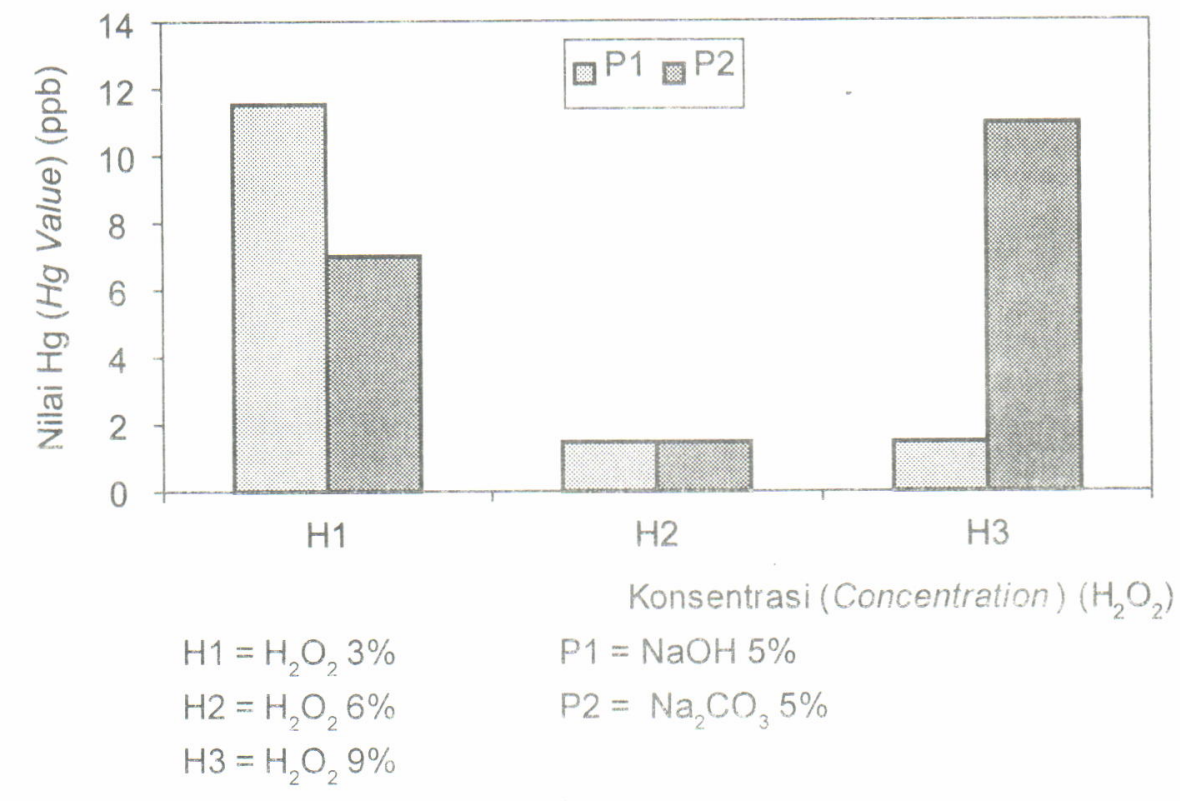

Gambar 6. Kadar merkuri (Hg) sodium alginat dari berbagai kombinasi perlakuan pemucatan dan pengendapan

Figure 6. Mercury $(\mathrm{Hg})$ content of sodium alginate treated by different concentration of bleaching agent and precipitant 
Kombinasi perlakuan terbaik adalah $\mathrm{H}_{2} \mathrm{P}$, yaitu ekstrak rumput laut yang dipucatkan dengan $\mathrm{H}_{2} \mathrm{O}_{2} 6 \%$ dan diendapkan dengan menggunakan $\mathrm{Na}_{2} \mathrm{CO}_{3} 5 \%$. Kombinasi perlakuan $\mathrm{H}_{2} \mathrm{P}_{1}$ dapat mewakili nilai terbaik dari parameter yang diuji dan memenuhi standar Food Chemical Codex. Perlakuan $\mathrm{H}_{2} \mathrm{P}_{1}$ menghasilkan rendemen sebesar $13,5 \%$; nilai kekentalan $237,8 \mathrm{cps}$; kadar susut pengerungan $14,5 \%$; derajat putih $53,7 \%$; kadar abu 25,3\%; kandungan logam As 1,083 ppb; logam dan kandungan logam $\mathrm{Hg}$ sebesar $1,5 \mathrm{ppb}$

\section{DAFTAR PUSTAKA}

Anonimous. 1981. Food Chemical Codex. $2^{\text {nd }}$ Ed. National Academic of Science, Washington DC. p. 155 195.

Basmal, J., Yunizal, dan J.T. Murtini. 2000. Pengaruh volume dan waktu ekstraksi natrium alginat dalam larutan natrium karbonat. Prosiding Pra KIPNAS VII. Forum Komunikasi I. Ikatan Fikokoloid Indonesia. Forum Organisasi Profesi IImiah. p. 119-126.

Chapman, V.J. and D.J. Chapman. 1980. Seaweed and Their Uses. $3^{\text {rd }}$ edition. Chapman and Hall, New York.

Chou, H.N. and Y.M. Chiang. 1976. Studies on Algin from Brown Algae of Taiwan I. Estimation of yield and quality of algin. Acta Oc. Taiwan. The National Taiwan University, Taiwan. (6): 135-140

Cottrel, W. and P. Kovacs. 1980. Alginates. In: Davidson, R.L. (Ed.). Handbook of Water Soluble Gums and Resin. McGraw-Hill Book Co, New York. p. 2-43.

McHugh, D.J. 1987. Production, properties, and uses of alginates. In: McHugh, D.J. (Ed.). Production and Uti- lization pf Product from Commercial Seaweed. FAO. Fisheries Technical Paper, Rome. p. 49-81

Murtini, J.V., J. Basmal, dan Yunizal. 2000a. Pengaruh bahan pemutih dan volume kalsium klorida terhada mutu kalsium alginat. Prosiding Pra KIPNAS VII. Forum Komunikasi I. Ikatan Fikokoloid Indonesia. Forum Organisasi Profesi IImiah. p. 85-90. $2000^{\mathrm{b}}$. Pengaruh

Pemucatan dan $\mathrm{pH}$ filtrat terhadap mutu natrium alginat. Prosiding Pra KIPNAS VII. Forum Komunikasi I. Ikatan Fikokoloid Indonesia. Forum Organisasi Profesi llmiah. p. 91-96.

Percival, E. 1970. Algae polysaccharides. In: Pigman, W. and D. Horton (Eds.). The Carbohydrates Chemistry and Biochemistry. $2^{\text {nd }} \mathrm{Ed}$. Academic Press, New York. 298 pp.

Sari, L.A. 1994. Pengaruh Penggunaan $\mathrm{NaOH}$ serta Pemurnian Metanol dan Isopropanol terhadap Rendemen dan Mutu Sodium Alginat dari Sargas.sum aquifolium. Skripsi, Fakultas Perikanan, IPB. $165 \mathrm{pp}$.

Yani. M. 1988. Modifikasi dan Optimasi Proses Ekstraksi dalam Rancang Bangun Proses Tepung Algin dari Jenis Turbinaria ornata. Skripsi. Fakultas Teknologi Pertanian, IPB, Bogor. $130 \mathrm{pp}$.

Winarno, F.G. 1990. Teknologi Pengolahan Rumput Laut. Pustaka Sinar Harapan, Jakarta.

Wiwekaningtyas, W. 1994. Optimalisasi Isolasi Sodium Alginat dari Turbinaria conoides dengan Menggunakan Dua Macam Perlakuan Asam $\left(\mathrm{HCl}\right.$ dan $\left.\mathrm{H}_{2} \mathrm{SO}_{4}\right)$. Skripsi, Fakultas Perikanan, IPB. 145 pp. 